\title{
Modelling of Dam-Weir Operations for Environmental Quality
}

\author{
Darrien Y.S. Mah and Frederik J. Putuhena
}

\begin{abstract}
It is the desire of many societies to have clean and safe potable water sources. As manmade structures are built in water supply catchments for the purposes to increase safe yield, then facilities management of these structures should be steered towards environmental quality. Hydraulics over a weir is well studied. However, this paper probes into benchmarking of flows over a Batu Kitang Weir to guide operations of an upstream Bengoh Dam in Sarawak, Malaysia. Flow releases from the dam are tried and routed through Sarawak Kiri River to achieve supercritical states at weir by means of computer modelling. For daily dam-weir operations, the modelling results suggest a condition of $20 \mathrm{~m}^{3} / \mathrm{s}<$ dam releases $<200 \mathrm{~m}^{3} / \mathrm{s}$ to meet raw water demand as well as adequate river flow regulation.
\end{abstract}

Keywords: environmental flow, hydrodynamic, InfoWorks RS, regulated river, water resources

\section{BACKGROUND}

$\mathrm{K}$ UCHING city of Sarawak State, Malaysia relies on Sarawak Kiri River for drinking water, in which the basin is gazette as Water Supply Catchments since 1993. In order to increase raw water yield of the river, a sheet pile weir is positioned across Sarawak Kiri River in Batu Kitang completed in 2005 [1]. A water treatment plant is located about $700 \mathrm{~m}$ from the weir. Further to secure water resources for the capital city, a roller-compacted concrete (RCC) Bengoh Dam is erected $38 \mathrm{~km}$ upstream of Batu Kitang Weir (see Figure 1) and completed by end of 2010. However, impoundment has not started during the writing of this paper. The dam with $77.5 \mathrm{~m}$ full supply level (see Figure 2) is meant solely as enduring water storage not for direct abstraction but to regulate flow along Sarawak Kiri River [2]. The catchment at the dam site represents about 20\% of that at Batu Kitang.

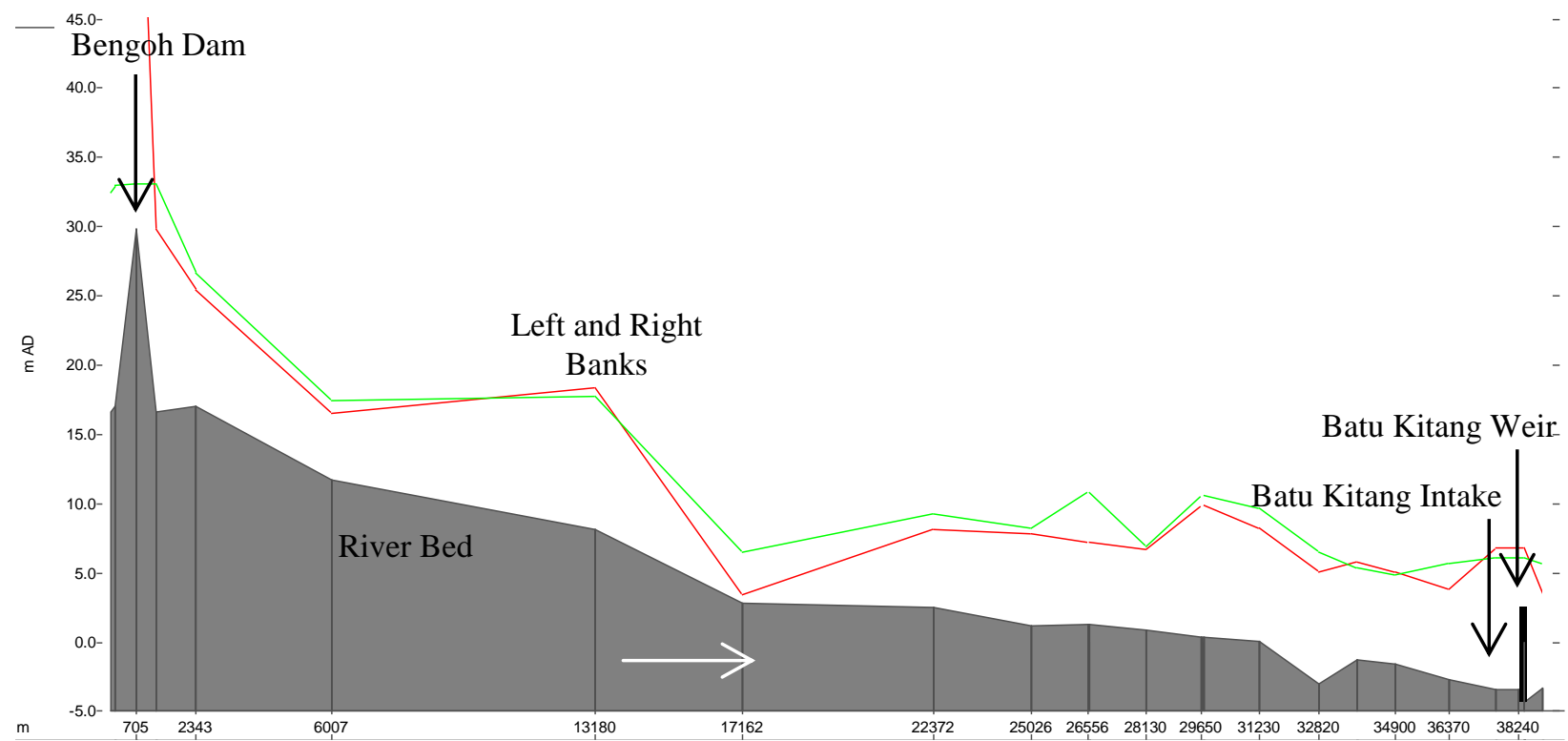

Figure 1. 38-km Long Section Profiles of Sarawak Kiri River

Dr Darrien Y.S. Mah is with the Department of Civil Engineering, Faculty of Engineering, Universiti Malaysia Sarawak, 94300 Kota Samarahan, Sarawak, Malaysia (corresponding author, phone: 082-5832077; fax: 082-583409; e-mail: ysmah@ feng.unimas.my).

Prof Dr Frederik J. Putuhena is with the Department of Civil Engineering, Faculty of Engineering, Universiti Malaysia Sarawak, 94300 Kota Samarahan, Sarawak, Malaysia (e-mail: fjputuhena@feng.unimas.my). 


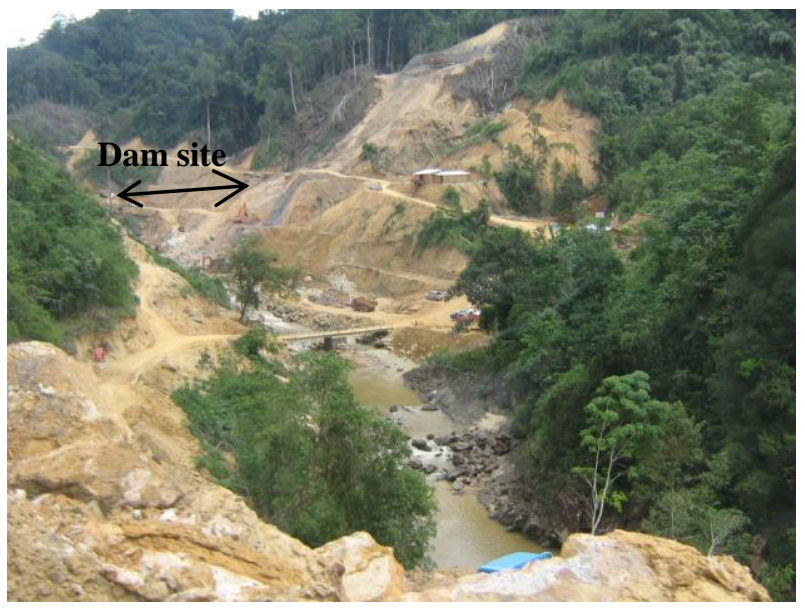

(a)

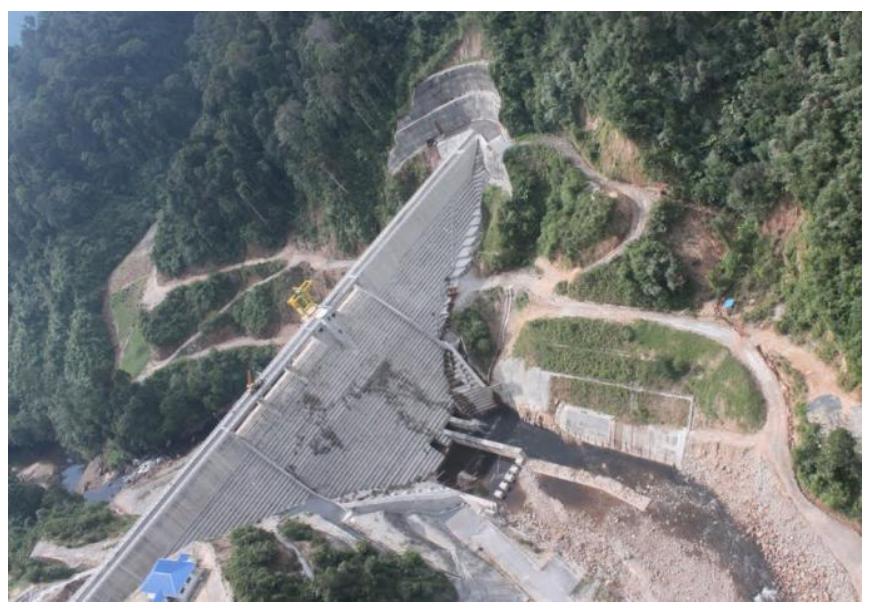

(b)

Figure 2. Bengoh Dam, (a) Photo taken in August 2008, and (b) Photo taken in April 2011

River water as natural resources is a necessary amenity for societies. Long term water supply scheme for Kuching city would consist of Batu Kitang Intakes, Batu Kitang Weir and Bengoh Reservoir. As such, Sarawak Kiri River has changed from a natural to regulated regime. The operations of these facilities would have major impact on the health of river [3] and therefore presented a need for proper operation management. There are numerous reports of important rivers in the world that have suffered significant environmental impacts due to man-made changes to natural regimes. For example, River MurrayDarling of Australia is a well-known river with multiple water controlled structures that evident for water quality decline [4]. A series of dams, weirs and five barrages have generally reduced the flow variability [5]. Water level upstream remains at a fairly constant level for long periods [6] to cause deterioration of the riverine environments of Murray-Darling basin [7].
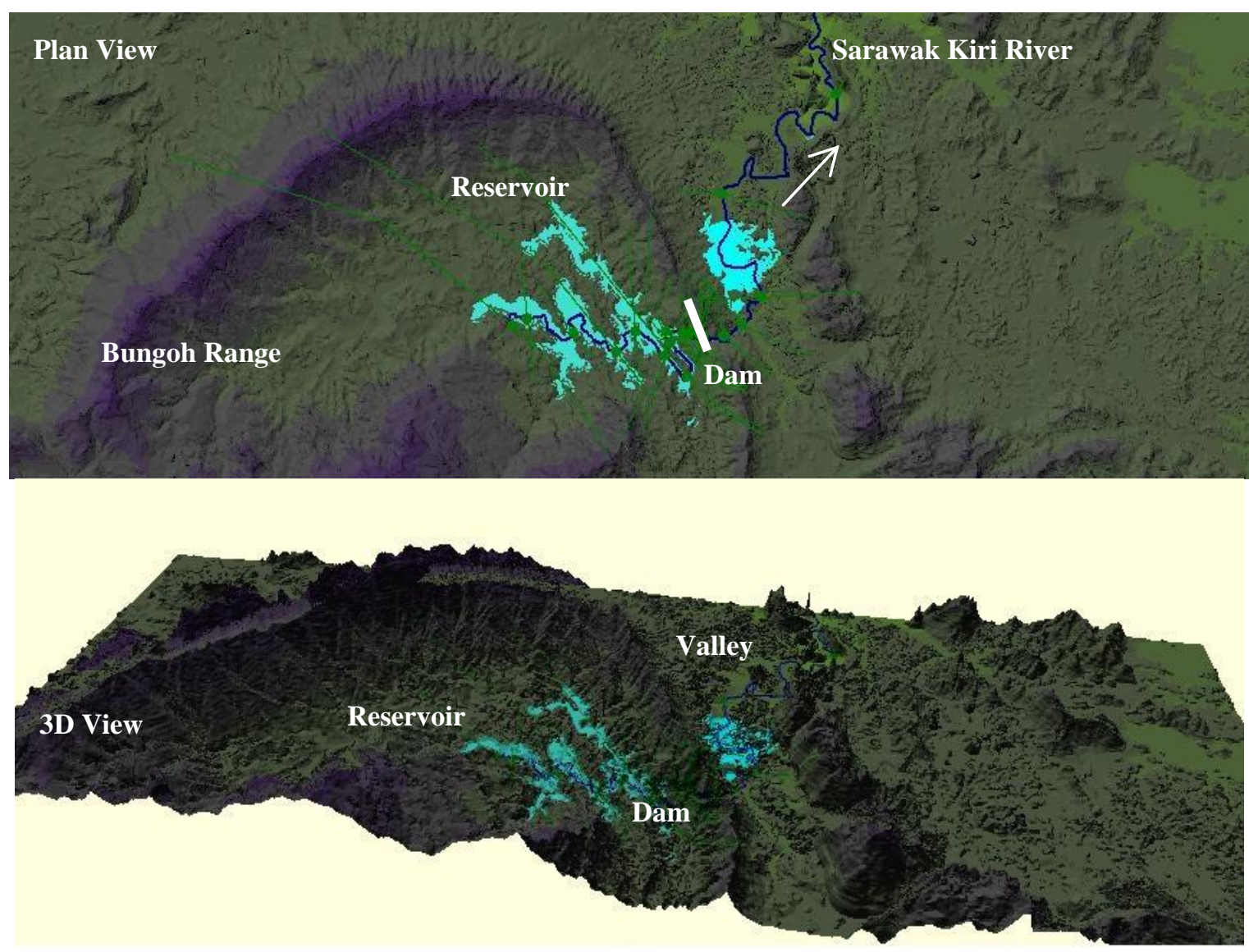

Figure 3. Modelling of Bengoh Dam and Sarawak Kiri River 
Reservoir and downstream regulated river share a common origin and unidirectional relationship [8]. With Bengoh Dam at the upstream end of river, Sarawak Kiri River flow depends on the dam release. With Batu Kitang Weir at the downstream end, the flow can be in stagnation states if too little flow is discharged through the dam. From the river engineering standpoint, flow on top of weir should sufficiently be in supercritical states. It means that the flow regime is always turbulent in most cases, enabling aeration of water downstream as one of its significant functions. Once flow goes beyond supercritical state, called the drowned condition, the weir has little impact on flow. Therefore, the release of Bengoh Dam can be potentially maneuvered towards achieving supercritical conditions at weir to provide a desire flow condition [9]. In this case, river modelling is capable of to speculate the dam releases [10].

\section{METHODS}

A hydrodynamic InfoWorks River Simulation (RS) model is utilized for modelling the hydraulics of Sarawak Kiri River systems (see Figure 3). The model building is of typical 1-D hydraulic model [11]. A base model representing the existing conditions with weir has been calibrated and validated to at least $80 \%$ of confidence. After that, dam is added for investigation. InfoWorks RS is not meant to model a dam, and therefore no report of the software is used on dam modelling before. However, we attempt here to model Bengoh Dam as a high gate river structure with spill unit. After the completion of dam construction, there would be followed by environmental assessment and water impoundment for one and half year. At the current stage, field data on the dam releases are not available.

\section{RESULTS AND DISCUSSION}

Bengoh Dam is designed to operate as a water reservoir dam. Release of raw water all year round would provide sufficient raw water supply for Batu Kitang water treatment plant. As water demand increases, the incidence of drawdown at the end of drier period of the year (September-October) would increase therefore providing some flood absorption during Monsoon season (November-December). The model running provides a guide on the volume of water to be released by benchmarking the conditions at Batu Kitang Weir. In the absence of any real dam release data, the modellers have to try out different flow rates, starting from as low as $10 \mathrm{~m}^{3} / \mathrm{s}$ to as high as $800 \mathrm{~m}^{3} / \mathrm{s}$.

Referring to Figure 4, three cross sections at the vicinity of weir are selected to portray the long section profiles at weir. In the cases of low dam releases (as in Figure 4b), 10, 20 and $50 \mathrm{~m}^{3} / \mathrm{s}$ of water volumes are routed through the braided Sarawak Kiri River. The consequences of water level range before weir is rather small and the water level after weir remains unchanged for all three flow scenarios. All three scenarios achieve supercritical state at weir. However, for flows of $10 \mathrm{~m}^{3} / \mathrm{s}$ when routed through the river from dam to weir, the model predicts a low velocity ranges between 0.013 to $0.027 \mathrm{~m} / \mathrm{s}$ due to differences in river sections and river shapes. Such low velocities are not favorable because it would provide a condition for natural algae to bloom in tropical climate thus causing water eutrophication processes. High concentration of algae in river water is toxic to most biota. It is based on this fact that the modellers suggested a minimum dam release of $20 \mathrm{~m}^{3} / \mathrm{s}$.

In the cases of high dam releases (as in Figure 4c), flows of 100, 200, 500 and $800 \mathrm{~m}^{3} / \mathrm{s}$ are tested. Water levels both up and downriver of weir are all most in equal levels when the dam releases are 500 and $800 \mathrm{~m}^{3} / \mathrm{s}$. Such condition is beyond supercritical state as drown condition that indicates the dam releases are too high. Note that any water level approaching +3.0 $\mathrm{m}$ in Batu Kitang would expect the occurrence of bank-burst and causing flooding in the area. In order to avoid unnecessary flooding to Batu Kitang area, the modelers suggested a maximum dam release of $200 \mathrm{~m}^{3} / \mathrm{s}$. Because at this volume of water, the model predicts a water level of $2.0 \mathrm{~m}$ before the weir and this allows a free board of $1 \mathrm{~m}$ in the river channel that would safeguard the nearby populated river stretches.

\section{CONCLUSION}

This study has been conducted to review the flow releases of Bengoh Dam to ensure a healthy Sarawak Kiri River to supply raw water sources to Kuching city. InfoWorks RS is adopted for modelling of the Bengoh Dam reservoir and downstream Batu Kitang Weir. The simulation results show that a flow range of above $20 \mathrm{~m}^{3} / \mathrm{s}$ and below $200 \mathrm{~m}^{3} / \mathrm{s}$ would achieve the desired supercritical conditions at weir. It demonstrates that InfoWorks RS is satisfactorily capable of providing a clear picture to support dam-weir operations.

\section{ACKNOWLEDGMENT}

The authors express gratitude to Universiti Malaysia Sarawak for providing the opportunity and supports to conduct this research. Special thanks to Ryan Hardin for assisting in the computer modelling. 


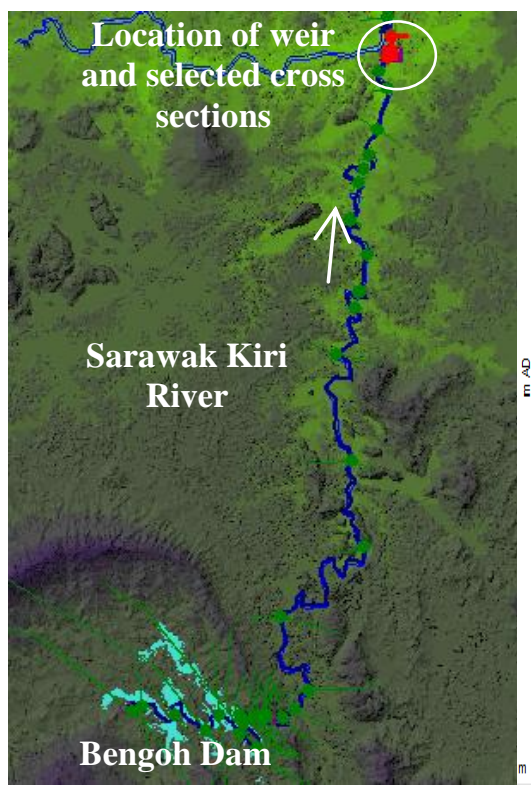

(a)

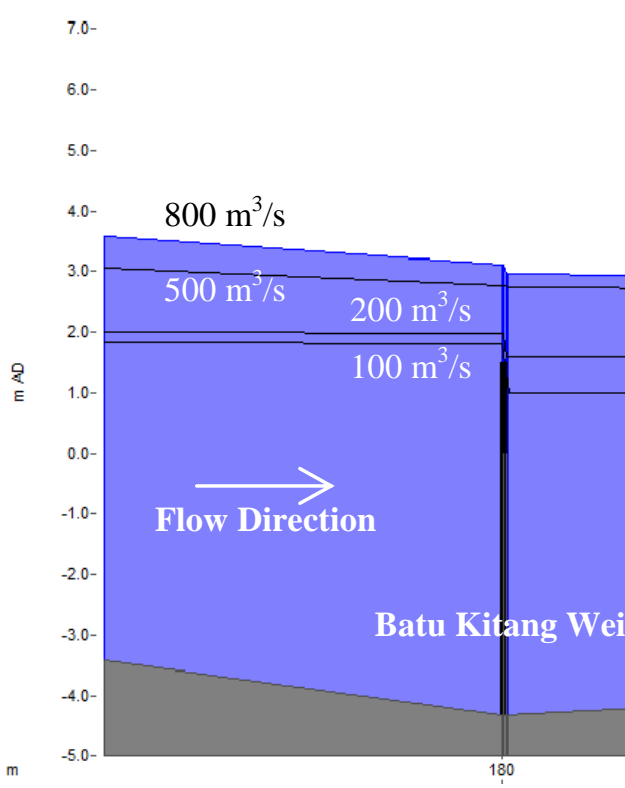

Figure 4. Predicted Water Levels at Batu Kitang Weir Subjected to Dam Releases, (a) Selected cross sections, (b) Low dam releases of 10, 20 and $50 \mathrm{~m}^{3} / \mathrm{s}$, and (c) High dam releases of 100, 200, 500 and $800 \mathrm{~m}^{3} / \mathrm{s}$

\section{REFERENCES}

[1] D.Y.S. Mah, F.J. Putuhena, L.H. Ngu, and S.H. Lai, "Modelling of Batu Kitang submersible weir in Kuching, Malaysia," The IUP Journal of Water and Soil Sciences, Volume II, No 3, pp. 25-38, August 2009.

[2] KTA Consulting Engineers. (2003). Proposed Bengoh Dam, Sarawak Phase 1 - Assessment Study. Final report for the State Government of Sarawak, Malaysia.

[3] R.H. Norris, and M.C. Thoms, "What is river health?” Freshwater Biology, 41, pp. 197-209, 1999.

[4] B. Shuttleworth, A. Woidt, T. Paparella, S. Herbig, and D. Walker, "The dynamic behaviour of a river-dominated tidal inlet, River Murray, Australia," Estuarine, Coastal and Shelf Science, Volume 64, Issue 4, pp. 645-657, September 2005.

[5] K.F. Walker, "Serial weirs, cumulative effects: the Lower River Murray, Australia," in The Ecology of Desert Rivers, R.T. Kingford, Ed. New York: Cambridge University Press, ISBN-13: 9780521818254, 2006.

[6] C. Gippel, T. Jacobs, and T. McLeod, "Environmental flows and water quality objectives for the River Murray," Water Science and Technology, Volume 45, Issue 11, pp. 251-260, 2002.

[7] R.A. Frick, R.P. Bourman, and D. Lucic, "Towards a control model for the Murray Mouth," Environmental Modelling and Assessment, Volume 1, Numbers 1-2, pp. 37-44, March 1996.

[8] A. Palau, "Integrated environmental management of current reservoirs and regulated rivers," Limnetica, Volume 25, Issues 1-2, pp. 287-302, 2006.

[9] C. Harman, and M. Stewardson, "Optimizing dam release rules to meet environmental flow targets," River Research and Applications, Volume 21, Issues 2-3, pp. 113-129, 2005.

[10] L.F.G. Lopes, J.S.A.D. Carmo, R.M.V. Cortes, and D. Oliveira, "Hydrodynamics and water quality modelling in a regulated river segment: application on the instream flow definition," Ecological Modelling, 173, pp. 197-218, 2004.

[11] K.K. Jenny, D.Y.S. Mah, F.J. Putuhena, and S. Salim, "Post-flood forensic analysis of Maong River using InfoWorks River Simulation (RS)," Journal Institution of Engineers, Malaysia, Volume 68, Issue 4, pp. 41-46, 2007. 